\title{
Pulses as Culturally Important Foods among University Students in Canada
}

\author{
Kristie Masuda $^{1}$ \\ ${ }^{1}$ Faculty of Health Sciences, University of Lethbridge, Lethbridge, Canada \\ Correspondence: Kristie Masuda, Faculty of Health Sciences, University of Lethbridge, Lethbridge, AB, T1K \\ 3M4, Canada. E-mail: kristie.masuda@uleth.ca
}

Received: April 29, 2018

Accepted: May 25, 2018 Online Published: June 5, 2018

doi:10.5539/jfr.v7n5p1

URL: https://doi.org/10.5539/jfr.v7n5p1

\begin{abstract}
Pulses such as beans and lentils are culturally important foods in different countries/regions due to their traditional role in dishes, which may be a result of a combination of their nutritive qualities, low cost, and ease of storage. Despite the cultural, health, and monetary benefits associated with eating pulses, pulse consumption in Canada is low. The present study attempted to address whether cultural factors influence pulse consumption among university students in Canada. Results showed that $59 \%$ of respondents' cultural identities do not impact their food choices, and just $29 \%$ indicated that pulses are part of their traditional diet.
\end{abstract}

Keywords: pulses, beans, lentils, culture, traditional diet, university students

\section{Introduction}

Pulses are the low-fat, dry, edible seeds that are harvested from pods of annual leguminous plants. Across the globe, the most commonly eaten pulses include kidney beans, navy beans, fava beans, chickpeas, dried or split peas, mung beans, black-eyed peas, and several varieties of lentils (Food and Agriculture Organization of the United Nations, 2016). Canada is the second largest producer of pulse crops in the world (Hoover, Hughes, Chung \& Lui, 2010), with the most commonly grown pulse crops being lentils (Lens culinaris), chickpeas (Cicer arietinum), dry beans (primarily Phaseolus vulgaris), and dry peas (Pisum sativum) (Tosh \& Yada, 2010).

Although Canada is a large global exporter of many pulse crops (Hoover et al., 2010), Canadians typically do not regularly eat pulses, with only $13 \%$ of the population consuming pulses on a daily basis (Ramdath, Renwick, \& Duncan, 2016). The estimated median weekly consumption of cooked pulses among Canadians is 1.0 cup per person, with South Asian immigrants consuming an average of 2.5 cups per week (Ipsos Reid, 2010). The large consumption differences between the general Canadian population and the South Asian immigrant population demonstrates that pulse consumption in Canada likely does not compare to that of other countries around the world.

Pulses are a culturally important food in different countries/regions due to their traditional role in dishes, which may be a result of a combination of their nutritive qualities, low cost, and ease of storage. Pulses, particularly beans, have been a staple food among most Latin American populations, which continues to impact the amount of pulses consumed by individuals within these ethnic groups (Leterme \& Carmenza Muñoz, 2002). For example, in the United States, people of Hispanic origin are the leading consumers of pinto beans, which constitute 47\% of the total dry beans consumed (Lucier, Lin, Allshous \& Kantor, 2000). Additionally, beans are a substantial part of the traditional Brazilian diet, and within this country, an adequate consumption of beans is associated with protection against a number of diseases (Velásquez-Meléndez et al., 2012).

Pulse crops also make up a large portion of dietary protein for many in countries where the consumption of animal protein is not permitted due to cultural or religious traditions and practices, or because it is not accessible to many in the population due to high costs. As a lower cost alternative to meat protein, many populations rely on plant-based proteins such as pulses to meet their dietary requirements. Pulses, particularly lentils, are often used as a meat substitute in developing countries (Erskine, Sarker \& Kumar, 2011). People in developing nations often rely on pulses for protein and energy requirements, as vegetable proteins are the most beneficial in terms of cost for a large proportion of populations in impoverished countries (Singh, Chung, \& Nelson, 2007). Pulse crops can provide nutritional security to low-income individuals in developing nations, particularly in Asia 
(Erskine et al., 2011). Although they are a cost effective, high-protein food for many low-income individuals, lentils are consumed widely by all income levels in many countries such as Sri Lanka due to their cooking convenience (Anoma, Collins, \& McNeil, 2014).

Despite the cultural, health, and monetary benefits associated with eating pulses, pulse consumption in Canada is low. Globally, there are some shared and unique factors that influence pulse consumption at the individual and population level. Common factors include an individual's level of education (Mfikwa \& Kilima, 2014; Velásquez-Meléndez et al., 2012), perceived health benefits (Ipsos Reid, 2010; Velásquez-Meléndez et al., 2012), being part of one's traditional diet (Ipsos Reid, 2010; Leterme \& Carmenza Muñoz, 2002; Lucier et al., 2000; Velásquez-Meléndez et al., 2012), and geographic location (i.e. rural/urban) (Leterme \& Carmenza Muñoz, 2002; Mfikwa \& Kilima, 2014; Velásquez-Meléndez et al., 2012). These studies show that there is a clear lack of data on university students in the current literature, and the present study attempted to fill the gaps to address whether cultural factors influence pulse consumption among university students in Canada.

\section{Methods}

An online cross-sectional survey design was implemented to collect quantitative data for the purpose of summarising attitudes, opinions, and trends within the sample population. An online survey was the preferred type of data collection procedure because of the rapid turnaround in data collection, the economy of the design, greater generalisability, and external validity. The study was approved by the University of Lethbridge Human Subjects Research Ethics Board in November 2017.

The population for this online survey study was drawn from the University of Lethbridge student body, which had 8,558 students in the fall term of 2017 (University of Lethbridge, 2017). This study sought participants specifically from the University of Lethbridge because of the proximity of the university to the researcher and because many pulse crops are grown in and around this area. The inclusion criteria include full- or part-time students aged 18 years or older currently attending the University of Lethbridge. This population was sought out using convenience and snowball sampling. Data collection took place over a three-week period in November and December of 2017. Analysis was assisted through the use of IBM SPSS Statistics 25 software.

\section{Results}

A total of 268 responses were received for the survey, all of which were used in the analysis. These participants constituted approximately $3 \%$ of the total University of Lethbridge student body, which was 8,558 in the fall term of 2017 (University of Lethbridge, 2017).

The majority of respondents had a European ethnic background (70\%). The other main ethnic backgrounds of participants were Asian (10\%), Indigenous North American (4\%), African (3\%), and Latin, Central or South American (3\%) (see Table 1).

Table 1. Demographic Characteristics of University of Lethbridge Students

\begin{tabular}{lr}
\hline Variable & $\%$ \\
\hline Main Ethnic Background $(\mathrm{n}=264)$ & \\
Indigenous North American & 3.79 \\
British or Irish & 32.95 \\
Continental European & 37.50 \\
West Indian/Caribbean & 0.76 \\
Latin, Central or South American & 2.65 \\
East or Southeast Asian & 5.30 \\
South Asian & 4.55 \\
West Central Asian/Middle Eastern & 0.38 \\
African & 2.65 \\
Other & 6.82 \\
Don't know & 2.65 \\
\hline
\end{tabular}

Daily pulse consumers made up just $6 \%$ of participants, $27 \%$ eat pulses four or more times per week, and nearly half of the respondents (49\%) eat pulses just one to three times per month. Five per cent of participants indicated that they typically eat more than three cups of pulses per week, $22 \%$ eat between one and three cups per week, $35 \%$ eat between one-quarter cup and one cup of pulses per week, $27 \%$ eat less than one-quarter cup per week, and $10 \%$ typically eat no pulses in a week. Chickpeas (28\%), black beans (22\%), and kidney beans (19\%) were the most commonly eaten pulses among this group (see Figure 1). 


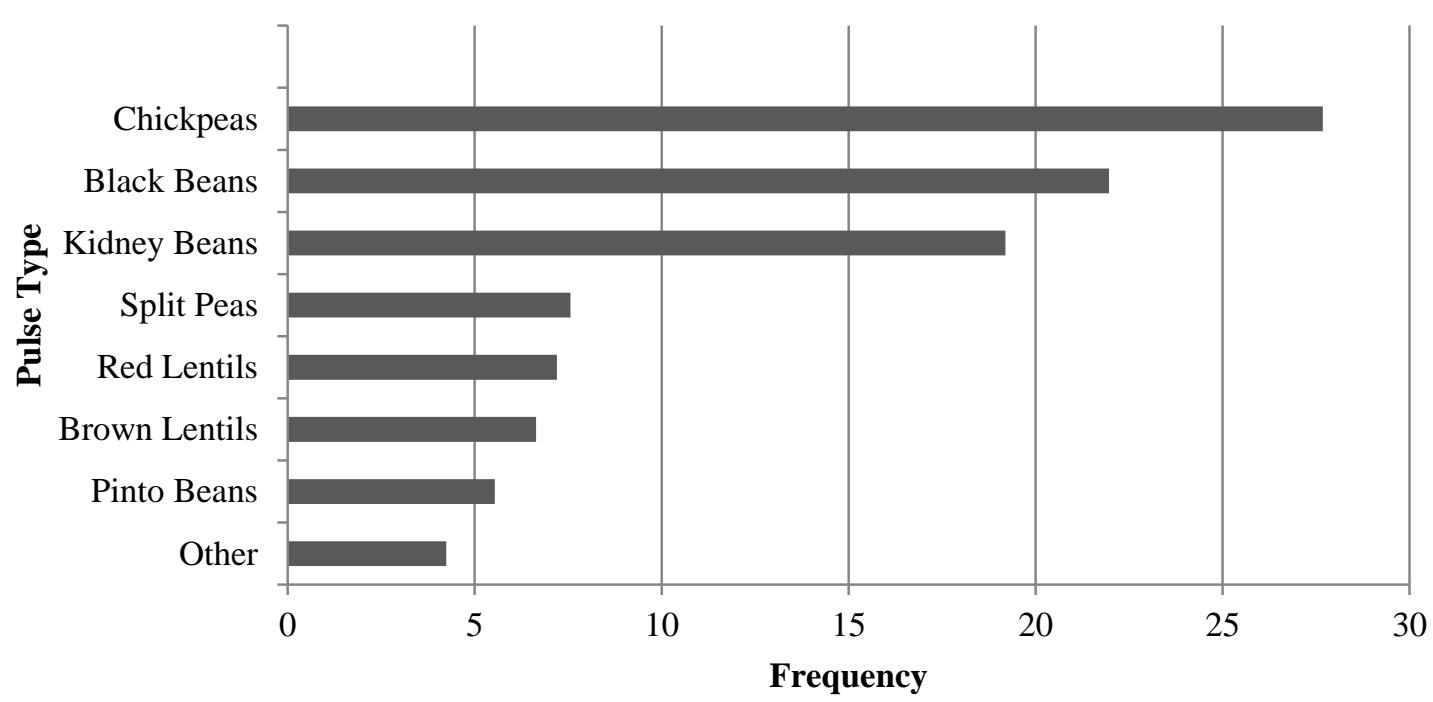

Figure 1. Most commonly consumed pulses. Split peas, red/brown lentils, and pinto beans were the least common types of pulses consumed from the specified list of pulses provided in this survey question

A large percentage (59\%) of respondents indicated that their cultural identity does not impact their food choices, with just $29 \%$ indicating that pulses are part of their traditional diet (see Table 2).

Table 2. Weighted Percentages of Level of Agreement About Knowledge and Attitudes Towards Pulses Regarding Cultural Identity and Traditional Diet

\begin{tabular}{llllll}
\hline & $\begin{array}{l}\text { Strongly } \\
\text { disagree }\end{array}$ & $\begin{array}{l}\text { Some-what } \\
\text { disagree }\end{array}$ & $\begin{array}{l}\text { Neither agree } \\
\text { nor disagree }\end{array}$ & $\begin{array}{l}\text { Some-what } \\
\text { agree }\end{array}$ & $\begin{array}{l}\text { Strongly } \\
\text { agree }\end{array}$ \\
\hline Pulses are part of my traditional diet & 20.31 & 26.95 & 23.83 & 20.70 & 8.20 \\
My cultural identity affects my food choices & 35.46 & 23.11 & 16.33 & 14.34 & 10.76 \\
\hline
\end{tabular}

One-Way ANOVA tests were performed to determine whether the participants vary in both the frequency and amount of pulses consumed based on their main ethic background. There was no significant difference among participants from different ethnic backgrounds on frequency $F(10,251)=1.530, p=.129$ or amount $F(10,237)$, $p=.211$ ) of pulses consumed in a week.

\section{Discussion}

Ethnic background has been shown to play a role in levels of pulse consumption (Ipsos Reid, 2010; Leterme \& Carmenza Muñoz, 2002; Lucier et al., 2000; Velásquez-Meléndez et al., 2012). People of Hispanic origin consume proportionately more cooked dried beans than and other ethnic group in the United States (Lucier et al., 2000), thus, the significantly lower number of Hispanics in the location of the present study compared to that of many centres in the United States likely affected these results. In 2016, 17.8\% of the population in the United States identified as Hispanic or Latino (United States Census Bureau, 2016), compared to $2.6 \%$ of participants in this study, and $2.3 \%$ of Lethbridge residents identifying with Latin, Central and South American origins (Statistics Canada, 2016). The majority of participants in this study do not have a main ethnic background that typically eats a large amount of pulses - such as Hispanic or South Asian - therefore, it is difficult to determine whether the ethnic background strongly affects consumption within the overall university population.

Traditional foods are often an important part of cultural identity, and a shift away from traditional food has been shown to negatively affect physical and mental health (Bersamin, Zidenberg-Cherr, Stern \& Luick, 2007; Delisle, 2010; Ebbesson, Risica, Ebbesson, Kennish \& Tejero, 2005; Kant, Vertinsky, Zheng, \& Smith, 2013; Koga et al., 2016; Lee, Popkin \& Kim, 2002; Loring \& Gerlach, 2009; McGrath-Hanna, Greene, Tavernier, \& Bult-Ito, 2003; Mohatt et al., 2007; Patchell \& Edwards, 2014; Pufall et al., 2011; Sheehy et al., 2014). The consumption of traditional foods is seen as an important indicator of cultural expression, as it is a tie to personal well-being and culture, as well as an essential conveyer of holistic health and culture promotion (Willows, 2005). Thus, changes 
in the availability and accessibility of traditional foods are issues of both preserving culture and improving well-being.

It is possible that the $29 \%$ of participants in this study who indicated that pulses were part of their traditional diet are not able to access pulses due to food availability at on- and off-campus food establishments. For example, new students living in the majority of residence units at the University of Lethbridge are enrolled in a mandatory dining plan in which the funds can be used at several specified dining locations on campus (University of Lethbridge, 2017). If the dining locations at which the students have to eat as part oft the dining plan provided more bean and lentil options, the students could be more likely to purchase and eat them.

Results from this study may prove to be useful in being able to supply detailed information to on-campus eating establishments, providing them with information on students' pulse preferences and how impactful their cultural background is on their consumption of pulses. This information could help the staff at the on-campus food establishments to increase their confidence in the preparation of pulses, which could in turn make pulses more likely to appear on the menus, placing pulses within a typical student meal plan. The introduction of more pulse based food products on campus has the potential for consumer appeal and increased communication of the health benefits of pulses, building on the university's commitment to being more inclusive and diverse (Shen, 2017) by offering a wider variety of ethnic foods.

\section{Conclusion}

This research project has identified that, despite the importance of pulses to certain traditional diets, cultural factors do not have much influence pulse consumption among university students who participated in this survey. Limitations to food variety in and around campus may be preventing university students from accessing traditional foods. Diversifying food options to include pulses in and around the university campus could lead to improved overall well-being by increasing the consumption of these nutrient dense and low cost foods while also giving access to culturally important foods.

\section{Acknowledgements}

The author wishes to thank the students who participated in this study. Peter Kellett and Em Pijl are also gratefully acknowledged for providing research guidance, and assisting with Qualtrics, respectively.

\section{References}

Anoma, A., Collins, R., \& McNeil, D. (2014). The value of enhancing nutrient bioavailability of lentils: The Sri Lankan scenario. African Journal of Food, Agriculture, Nutrition and Development, 14(7), 9529-9543.

Bersamin, A., Zidenberg-Cherr, S., Stern, J. S., \& Luick, B. R. (2007). Nutrient intakes are associated with adherence to a traditional diet among Yup'ik Eskimos living in remote Alaska native communities: The CANHR study. International Journal of Circumpolar Health, 66(1), 62-70. https://doi.org/10.3402/ijch.v66i1.18228

Delisle, H. (2010). Findings on dietary patterns in different groups of African origin undergoing nutrition transition. Applied Physiology, Nutrition, and Metabolism, 35(2), 224-228. https://doi.org/10.1139/H10-008

Ebbesson, S. O. E., Risica, P. M., Ebbesson, L. O. E., Kennish, J. M., \& Tejero, M. E. (2005). Omega-3 fatty acids improve glucose tolerance and components of the metabolic syndrome in Alaskan Eskimos: The Alaska Siberia project. International Journal of Circumpolar Health, 64(4), 396-408. https://doi.org/10.3402/ijch.v64i4.18016

Erskine, W., Sarker, A., \& Kumar, S. (2011). Crops that feed the world 3. Investing in lentil improvement toward a food secure world. Food Security, 3, 127-139. https://doi.org/10.1007/s12571-011-0124-5

Food and Agriculture Organization of the United Nations. (2016). Nutritional benefits of pulses. Retrieved from http://www.fao.org/3/a-i5384e.pdf

Hoover, R., Hughes, T., Chung, H. J., \& Liu, Q. (2010). Composition, molecular structure, properties, and modification of pulse starches: A review. Food Research International, 43(2), 399-413. https://doi.org/10.1016/j.foodres.2009.09.001

Ipsos Reid. (2010). Factors influencing pulse consumption in Canada. Final Report. Retrieved from http://www1.agric.gov.ab.ca/\$Department/deptdocs.nsf/all/sis13117/\$FILE/v3_factors_influencing_pulse_c onsumption_final_report_feb24_2010.pdf

Kant, S., Vertinsky, I., Zheng, B., \& Smith, P. (2013). Social, cultural, and land use determinants of the health and well-being of Aboriginal peoples of Canada: A path analysis. Journal of Public Health Policy, 34(3), 
462-476. https://doi.org/10.1057/jphp.2013.27

Koga, M., Toyomaki, A., Miyazaki, A., Nakai, Y., Yamaguchi, A., Kubo, C., ... Kusumi, I. (2017). Mediators of the effects of rice intake on health in individuals consuming a traditional japanese diet centered on rice. PLoS One, 12(10), e0185816. https://doi.org/10.1371/journal.pone.0185816

Lee, M., Popkin, B. M., \& Kim, S. (2002). The unique aspects of the nutrition transition in South Korea: The retention of healthful elements in their traditional diet. Public Health Nutrition, 5(1a), 197-203. https://doi.org/10.1079/PHN2001294

Leterme, P., \& Carmenza Muñoz, L. (2003). Factors influencing pulse consumption Latin America. The British Journal of Nutrition, 88(3). 251-255.

Loring, P. A., \& Gerlach, S. C. (2009). Food, culture, and human health in Alaska: An integrative health approach to food security. Environmental Science and Policy, 12(4), 466-478. https://doi.org/10.1016/j.envsci.2008.10.006

Lucier, G., Lin, B.-H., Allshouse, J., \& Kantor, L. S. (2000). Factors affecting dry bean consumption in the United States. Vegetables and Specialites, 280, 26-34.

McGrath-Hanna, N. K., Greene, D. M., Tavernier, R. J., \& Bult-Ito, A. (2003). Diet and mental health in the arctic: Is diet an important risk factor for mental health in circumpolar peoples?--a review. International Journal of Circumpolar Health, 62(3), 228-241. https://doi.org/10.3402/ijch.v62i3.17560

Mfikwa, A. E., \& Kilima, F. T. M. (2014). Factors influencing the consumption of pulses in rural and urban areas of Tanzania. Tanzania Journal of Agricultural Sciences, 13(2), 59-74.

Mohatt, G. V., Plaetke, R., Klejka, J., Luick, B., Lardon, C., Bersamin, A., ... Center for Alaska Native Health Research. (2007). The center for alaska native health research study: A community-based participatory research study of obesity and chronic disease-related protective and risk factors. International Journal of Circumpolar Health, 66(1), 8-18. https://doi.org/10.3402/ijch.v66i1.18219

Patchell, B., \& Edwards, K. (2014). The role of traditional foods in diabetes prevention and management among Native Americans. Current Nutrition Reports, 3(4), 340-344. https://doi.org/10.1007/s13668-014-0102-6

Pufall, E. L., Jones, A. Q., McEwen, S. A., Lyall, C., Peregrine, A. S., \& Edge, V. L. (2011). Perception of the importance of traditional country foods to the physical, mental, and spiritual health of Labrador Inuit. Arctic, 64(2), 242-250. https://doi.org/10.14430/arctic4103

Ramdath, D., Renwick, S., \& Duncan, A. M. (2016). The role of pulses in the dietary management of diabetes. Canadian Journal of Diabetes, 40, 355-363. https://doi.org/10.1016/j.jcjd.2016.05.015

Sheehy, T., Kolahdooz, F., Schaefer, S. E., Douglas, D. N., Corriveau, A., \& Sharma, S. (2015). Traditional food patterns are associated with better diet quality and improved dietary adequacy in Aboriginal peoples in the Northwest Territories, Canada. Journal of Human Nutrition and Dietetics, 28(3), 262-271. https://doi.org/10.1111/jhn.12243

Shen, A. (2017, October 26). Canadian universities commit to progress on equity, diversity and inclusion. University Affairs. Retrieved from

http://www.universityaffairs.ca/news/news-article/canadian-universities-commit-progress-equity-diversity-i nclusion

Singh, R. J., Chung, G. H., \& Nelson, R. L. (2007). Landmark research in legumes. Genome, 50, 525-537. https://doi.org/10.1139/G07-037

Statistics Canada. (2016). Census profile, 2016 census. Retrieved from http://www12.statcan.gc.ca/census-recensement/2016/dp-pd/prof/details/page.cfm?Lang=E\&Geo1=POPC\& Code $1=0467 \& G e o 2=$ PR $\&$ Code $2=48 \&$ Data $=$ Count $\&$ SearchText=Lethbridge $\&$ SearchType $=$ Begins $\&$ Search $\mathrm{PR}=01 \& \mathrm{~B} 1=\mathrm{All}$

Tosh, S. M., \& Yada, S. (2010). Dietary fibres in pulse seeds and fractions: characterization, functional attributes, and applications. Food Research International, 43, 450-460. https://doi.org/10.1016/j.foodres.2009.09.005

University of Lethbridge. (2017). Fall 2017. Retrieved from http://www.uleth.ca/analysis/content/view-facts

University of Lethbridge. (2017). Residence Dining Plan. Retrieved from http://www.uleth.ca/housing/residence-dining-plan

Velásquez-Meléndez, G., Mendes, L. L., Pessoa, M. C., Luciana Monteiro Vasconcelos Sardinha, Renata Tiene 
de Carvalho Yokota, Regina Tomie Ivata Bernal, \& Malta, D. C. (2012). Trends in frequency of consumption of beans assessed by means of a telephone survey in Brazilian state capitals between 2006 and 2009. Ciência \& Saúde Coletiva, 17(12), 3363-3370. https://doi.org/10.1590/S1413-81232012001200021

Willows, N. (2005). Determinants of healthy eating in Aboriginal peoples in Canada. Canadian Journal of Public Health, 96, S32-S36.

\section{Copyrights}

Copyright for this article is retained by the author(s), with first publication rights granted to the journal.

This is an open-access article distributed under the terms and conditions of the Creative Commons Attribution license (http://creativecommons.org/licenses/by/4.0/). 